\title{
Potentially lactic acid bacteria as an EPS producing starter from yellow sweet potato fermentation
}

\author{
NETI YULIANA ${ }^{1, \bullet}$, SUMARDI $^{2}$, EDO JATMIKO ${ }^{1}$, MENTARI ROSALINE ${ }^{1}$, MUHAMMAD IQBAL ${ }^{2}$ \\ ${ }^{1}$ Department of Agroindustrial Technology, Faculty of Agriculture, Universitas Lampung. Jl. Prof. Sumantri Brojonegoro No. 1, Bandar Lampung 35145, \\ Lampung, Indonesia. Tel.: +62-721-701609,Fax.: +62-721-702767, ‘email: neti.yuliana@fp.unila.ac.id \\ ${ }^{2}$ Department of Biology, Faculty of Mathematics and Natural Sciences, Universitas Lampung. Jl. Prof. Sumantri Brojonegoro No. 1, Bandar Lampung \\ 35145, Lampung, Indonesia
}

Manuscript received: 14 July 2020. Revision accepted: 24 August 2020.

\begin{abstract}
Yuliana N, Sumardi, Jatmiko E, Rosaline M, Iqbal M. 2020. Potentially lactic acid bacteria as an EPS producing starter from yellow sweet potato fermentation. Biodiversitas 21: 4269-4275. Potentially lactic acid bacteria as a starter for EPS production from yellow sweet potato fermentation were determined. The fermentation profile and partial characteristics of isolated lactic acid bacteria were used as considerations. The fermentation of yellow sweet potato was performed in the back-slopping and spontaneous procedure and was paid attention to the hours of $0,24,48$, and 72 . The results showed that the 72 hours of fermentation was found to have the highest EPS metabolites, the most upper the number of a LAB, the highest total lactic acid, and the lowest $\mathrm{pH}$. The 72 hours of fermentation also seemed to cause a significant change in the sweet potato starch granules morphology. The potential starter, therefore, can be taken from the yellow sweet potato fermentation either spontaneously or by a back-slopping method, at 72 hours. From the sixty selected LAB, the 34 strains showed an ability to produce EPS. Among these, eight strains exhibited the potential high production of EPS. They were capable of growth on $28-45^{\circ} \mathrm{C}$ and exhibited tolerance to $3-4 \% \mathrm{NaCl}$. The favorable carbon sources for the growth and production of EPS were isolated dependent.
\end{abstract}

Keywords: Back-slopping, EPS, lactic acid bacteria starter, spontaneous, sweet potato

\section{INTRODUCTION}

White sweet potato (SP) is important food crop that has potential to be used in composite flour to substitute the wheat. The naturally sweet potato flour, however, has some drawbacks properties. Slightly dark color (Trejo-González et al. 2014), low viscosity (Aprianita et al. 2009), less swelling power (Yuliana et al. 2014), and low loaf volume when applied to bread products (Amal 2015), make the utilization of sweet potato flour as wheat substituted flour acceptable for consumers is still low. Thus, sweet potatoes that are processed into flour require a modification process to be more applicable flour for further processing. Modification of sweet potato flour can be done through lactic acid fermentation (Yuliana et al. 2014; Amajor et al. 2014; Liao and Wu 2017). Sweet potatoes flour made with lactic acid fermentation has better physicochemical properties and aroma (Yuliana et al. 2014; Liao and Wu 2017; Yuliana et al. 2017; Yuliana et al. 2018). Amylolyctic enzymes and acid action during lactic fermentation could change the structure of the starch granules (Diaz et al. 2018; Guo et al. 2019). Changes of the starch granule could lead to a modification in fermented SP starch or flour properties such as increasing peak viscosity and water-binding capacity, which in turn increasing the capacity of starch to swell quickly (Yuliana et al. 2014; Ajayi et al. 2016). Fermentation also improves the whiteness of SP flour by reducing component factors causing the browning (Yuliana et al. 2018). In terms of the aroma, in addition to organic acid, the functional groups such as hydroxyl, aldehydes, alcohol, and carboxyl are present in the fermented samples of SP flour (Ajayi et al. 2019). Besides, fermentation with the help of specific lactic acid bacteria can produce an exopolysaccharide (EPS), which is useful for improving the functional properties of flour. Many authors have explored the role of the EPS in strengthening some flour and or starch properties such as increase binding and water holding capacity, improve viscosity, stabilize gel structure and improve rheological parameters (Patel and Prajapati 2013; Karasu and Ermis 2019).

The lactic acid fermentation process can occur with the help of a starter of lactic acid bacteria (LAB). The progress in optimizing the growth factors of desired lactic acid bacteria will influence the success of the lactic acid fermentation process. These factors will provide different conditions for each type of starter according to their environment to affect the fermentation. Besides, each microbial starter will show differences in growth patterns, the period needed to grow and adapt, and the metabolites produced (Zajsek et al. 2013; Ajayi et al. 2016; Anino et al. 2019; Kurniadi et al. 2019).

Therefore, among others, the starter culture is essential to determine the efficiency of the fermentation process. The uses of the culture will help obtain the specific changes in the chemical composition, nutritional value, and sensorial properties of the substrate. By helping with a starter culture, the fermentation process, and consistent quality product with improved hygiene could be optimized (Ajayi et al. 2016). Therefore, it is a challenge to find out 
the starter culture with EPS-producing properties, and the data related to growth and metabolites produced can be considered to assess the potential of the starter used.

Starter's culture can be obtained from a liquid of backslopping fermentation or derived from a natural fermentation process. Isolation of microorganisms from these occurring processes has always been the most potent means for obtaining a useful culture. Back-slopping practice and the length of fermentation, drive the progress and outcome of fermentation processes as occurred on (back-slopped) sourdough (De Vuyst et al. 2017). The type of technology applied, such as back-slopping procedures, will ascribe to the selected predominance specific lactic acid bacteria (Vrancken et al. 2011).

So far, research into the lactic fermentation process of sweet potatoes by using starter culture from back-slopping and spontaneous fermentation methods have been reported (Yuliana et al. 2014; Amajor et al. 2014; Ajayi et al. 2016; Yuliana et al. 2017; Yuliana et al. 2018). However, the research on the potential sources of the LAB starter, especially for possibly EPS production of both fermentation methods, is not widely known. Therefore, this study aims to investigate lactic acid bacteria that have the potential to produce EPS from fermentation of yellow sweet potato (back-slopping and spontaneous). These bacterial isolates are expected to be used as a starter to further modify sweet potato flour

\section{MATERIALS AND METHODS}

\section{Plant material and fermentation of yellow sweet potatoes}

The main ingredient used in this study was a yellow sweet potato purchased at the traditional market in Bandar Lampung, Indonesia. The sweet potatoes were washed, peeled, sliced, and added to glassware containing a boiled solution of $3 \%$ salt-1\% sugar and were left at room temperature. The sweet potato slices were fermented with two procedures, one lot, namely back-slopping, and another lot was spontaneous fermentation. A starter, prepared by fermenting diced sweet potato in sterilized bottles containing 3\% saline and $1 \%(\mathrm{w} / \mathrm{w})$ sucrose solution for seven days at $37^{\circ} \mathrm{C}$ (Yuliana et al. 2018), was added to the lot for a back-slopping procedure. The inoculation rate was $10 \%$ based on the volume of the fermentation solution. Another lot that no starter addition was prepared as spontaneous fermentation. Each experimental unit was repeated three times. Observations on total LAB (Yuliana et al. 2013), and biochemical changes: $\mathrm{pH}$, total acidity as $\%$ of lactic acid, total glucose of supernatant (phenolsulphuric method), and amount of crude exopolysaccharide (Razack et al. 2013), were done at 0 (H0), 24 (H24), 48 (H48), and 72 hours (H72). A significant change in sweet potato starch granule at a selected hour of fermentation was also performed using scanning electron microscopy. Based on the above results, the potential lactic acid bacteria were then isolated and further observed for the candidate of exopolysaccharides (EPS)-producing lactic acid bacteria.

\section{Isolation of lactic acid bacteria (LAB)}

The fresh yellow sweet potato slices were added to glassware containing a boiled solution of salt-sugar, fermented with back-slopping until 72 hours, and then used as microbial sources. The sample was taken, and bacterial isolation was performed by plating on MRS agar (Oxoid) containing $0.1 \% \mathrm{CaCO} 3$ and was then incubated at $30^{\circ} \mathrm{C}$ for $48 \mathrm{~h}$. The colonies identified by the presence of clear zones around each colony were randomly selected by streaked plate method, and purified on MRS-agar plates. Colonies were reselected, plated on MRS agar, and incubated again at $30{ }^{\circ} \mathrm{C} \pm 2{ }^{\circ} \mathrm{C}$ for 24 hours. Gram staining, endospore, and catalase testing were performed for these selected colonies. Microorganisms categorized as lactic acid bacteria (gram-positive, negative endospore, and no catalase production) were purified on MRS agar and preserved at $4^{\circ} \mathrm{C}$ on MRS agar slants.

\section{Screening of exopolysaccharide-producing LAB}

Screening of EPS-producing LAB followed procedure based on the mucoid formation on the disc (Paulo et al. 2012), with little modification. The culture medium used for the screening of EPS-producing LAB was MRS agar supplemented with $10 \%$ skim milk, $3 \%$ sucrose, and $1 \%$ yeast extract. Four $\mu \mathrm{L}$ of culture from each selected were inoculated to the sterile filter paper $(5 \mathrm{~mm} \varnothing)$ and put in Petri dishes $(80 \mathrm{~mm} \varnothing)$ containing the culture medium agar. After $48 \mathrm{~h}$ incubation, EPS production was confirmed based on the formation of a thick slime (mucoid) colony around the discs. The precipitation of this mucoid substance after mixing in absolute alcohol was also performed (Paulo et al. 2012). The mucoid zone diameter was measured, and the dry precipitate was weighed to assess the crude EPS production by the isolates. The saturation of the discs was fixed by observing the mucoid substance of the selected sample in scanning electron microscopy (SEM). An array of fiber polysaccharides was revealed as EPS (Paulo et al. 2012). Following a screening of EPS-producing bacteria, selected bacteria with potential high EPS yield were tested for their survival at various temperatures $\left(10\right.$ and $45^{\circ} \mathrm{C}$ ), and $\mathrm{NaCl}$ concentrations (3$10 \%)$. Their endurance to temperature and salt was determined based on turbidity or sediment formation in the media. In addition, their ability to produce EPS in various sugar media was also carried out.

\section{Potentially EPS-producing LAB on various sugar medium}

The various medium conditions changing the type of sugar (sucrose, glucose, galactose, and lactose) were used for culturing the selected isolates. One $\mathrm{mL}$ of each isolate was inoculated into tubes containing $9 \mathrm{~mL}$ of nonfat skim medium (skim milk $10 \%$, yeast extract $1 \%$, and sugar $1 \%$ ). These tubes were incubated at $28 \pm 2^{\circ} \mathrm{C}$ for 24 hours. The EPS assessment followed procedure by Razack et al. (2013) with modification of the TCA precipitation step. After being incubated, the cells were removed by centrifugation at $4^{\circ} \mathrm{C}$ at $15.000 \mathrm{rpm}$ for $30 \mathrm{~min}$. The supernatant was taken for further purification by dissolving in $80 \%$ TCA and stirring for 30 minutes. The precipitated protein was removed by centrifugation at $15.000 \mathrm{rpm}$ for 
30 minutes at $4^{\circ} \mathrm{C}$, and the supernatants were precipitated by adding an equal volume of absolute cold ethanol. The mixture was stored overnight at $4^{\circ} \mathrm{C}$. The precipitated EPS was recovered by centrifugation at $4^{\circ} \mathrm{C}$ at $15.000 \mathrm{rpm}$ for $30 \mathrm{~min}$, dried at $60^{\circ} \mathrm{C}$, and its weight was determined as crude EPS.

\section{Data analysis}

The data generated on biochemical changes and total LAB were subjected to analysis of variance (ANOVA), and orthogonal polynomial contrast and comparison. Differences were reported at a significance level of 0.05 .

\section{RESULTS AND DISCUSSION}

\section{LAB and biochemical changes during fermentation}

The value of $\mathrm{pH}$, total acidity, crude EPS, residual reducing sugar, and lactic acid bacteria (LAB) are presented in Table 1. During fermentation, there was an increase in both treatments in total lactic acid, EPS, total $\mathrm{LAB}$, residual reducing sugar, and a decrease in the $\mathrm{pH}$. At the end of fermentation (72 hours), the back-slopping has a higher value of total acidity, crude EPS, reducing sugar, and a total of the LAB than those in spontaneous fermentation. Vice versa, the $\mathrm{pH}$ of the solutions in backslopping was lower than that in spontaneous fermentation. The range of $\mathrm{pH}$ values achieved in both spontaneous and back-slopping treatments was not different from the results reported by previous studies (Yuliana et al. 2018; Oloo et al. 2014). A decrease in $\mathrm{pH}$ during fermentation indicates organic acid accumulation, especially lactic acid (Othman et al. 2017: Thorat et al. 2017; Zhao et al. 2018).

During fermentation, the LAB grows by utilizing a source of sugar as energy sources (Vidra et al. 2017; Bintsis 2018) that can come from the degradation of starch in yellow sweet potato tissue. In $100 \mathrm{~g}$ of fresh material, a yellow sweet potato contains starches of $65.41 \%$ (dry basis) (Rodrigues et al. 2016). Amylase enzymes degrade yellow sweet potato starch during fermentation into polymers with shorter chains (simple sugars). Aside from LAB (Petrova et al. 2013), amylase was reported naturally on sweet potatoes (Ramakrishnan and Rathnasamy 2016). The LAB then uses simple sugar (glucose) as a source of energy or nutrition for its growth. In this fermentation, a rapid increase in reducing sugar in the substrate was observed in the 72 hours fermentation time, indicating that at this point, there was a faster growth rate of LAB (Table 1). An increase of LAB during the fermentation process with the back-slopping procedure was higher than those in natural treatment. The growth pattern of the LAB at the beginning of fermentation ( 0 hours) was possibly in the significant amount, and then it increased the next day until hour 72.

During LAB development, the exopolysaccharide was secreted into the extracellular matrix (Zeidan et al. 2017). The crude EPS content of fermented yellow sweet potato in all treatments increased linearly during fermentation with the back-slopping treatment $(1.07 \%)$ was lower than a natural rate $(0.9 \%)$. The differences were probably contributed by the types of the LAB that grow during the fermentation process. EPS production with BAL is influenced by the type of inoculum or is a strain-dependent property (Leroy and De Vuyst 2016). In addition to inoculum, EPS production was also fermentation timedependent. This study's results are in line with previous research, which showed an increase of EPS by lactic acid bacteria with a rise in incubation time (Onilude et al. 2013; Maalej et al. 2014; Rawal et al. 2016). The profile of this fermentation suggests that the potential LAB could be obtained from the back-slopping method, mainly at 72 hours of fermentation. This incubation time, therefore, was selected as the reference for the next step of the experiment.

Table 1. LAB and biochemical changes during fermentation

\begin{tabular}{|c|c|c|c|c|c|c|}
\hline & $\begin{array}{c}\text { Time of fermentation } \\
\text { (hour) }\end{array}$ & $\begin{array}{l}\text { LAB (log } \\
\text { cfu/mL) }\end{array}$ & pH & $\begin{array}{c}\text { Crude EPS } \\
(\mathrm{g} / \mathrm{mL})\end{array}$ & $\begin{array}{c}\text { Acidity } \\
(\%)\end{array}$ & $\begin{array}{c}\text { Reducing sugar } \\
(\mathrm{mg} / \mathrm{mL})\end{array}$ \\
\hline \multirow[t]{5}{*}{ Spontaneous } & 0 & $0.00 \pm 0.00$ & $6.43 \pm 0.40$ & $0.15 \pm 0.05$ & $0.06 \pm 0.01$ & $24.70 \pm 1.45$ \\
\hline & 24 & $6.79 \pm 0.36$ & $4.44 \pm 0.17$ & $0.53 \pm 0.09$ & $0.68 \pm 0.31$ & $29.47 \pm 3.91$ \\
\hline & 48 & $7.43 \pm 0.25$ & $3.95 \pm 0.09$ & $0.75 \pm 0.09$ & $1.22 \pm 0.19$ & $35.70 \pm 3.42$ \\
\hline & 72 & $7.03 \pm 0.44$ & $3.87 \pm 0.21$ & $0.95 \pm 0.06$ & $1.44 \pm 0.12$ & $44.01 \pm 2.05$ \\
\hline & Trendline & Quadratic* & Quadratic* & Linier* & Linier* & Linier* \\
\hline \multirow[t]{5}{*}{ Back-slopping } & 0 & $8.21 \pm 0.07$ & $4.50 \pm 0.26$ & $0.76 \pm 0.02$ & $0.81 \pm 0.25$ & $28.35 \pm 1.38$ \\
\hline & 24 & $8.21 \pm 0.11$ & $3.87 \pm 0.09$ & $0.81 \pm 0.03$ & $0.99 \pm 0.12$ & $33.42 \pm 1.08$ \\
\hline & 48 & $8.59 \pm 0.19$ & $3.67 \pm 0.06$ & $1.19 \pm 0.09$ & $1.44 \pm 0.15$ & $39.12 \pm 0.73$ \\
\hline & 72 & $8.68 \pm 0.14$ & $3.57 \pm 0.08$ & $1.45 \pm 0.11$ & $1.89 \pm 0.13$ & $49.49 \pm 1.89$ \\
\hline & Trendline & Quadratic* & Quadratic* & Linier* & Linier* & Linier* \\
\hline Comparison & $\begin{array}{c}\text { Spontaneous vs Back- } \\
\text { slooping }\end{array}$ & $*$ & $*$ & $*$ & $*$ & ns \\
\hline
\end{tabular}

Note: * significant at 0.05 by orthogonal polynomial contrast, ns: not significant 


\section{Granular starch of sweet potatoes}

Fermentation changes the structure of starch granules. Figure 1 shows the appearance of yellow sweet potato starch granules (controls without fermentation) that are not perforated. Meanwhile, yellow sweet potato starch granules experienced a change in shape at the end of fermentation time $(\mathrm{t}=72$ hours $)$, which suffered degradation in two different fermentation treatments. Similar results were reported on fermented yellow sweet potato starch granules by Lactobacillus plantarum (Liao and Wu 2017). Changes in starch granules were also reported during the spontaneous fermentation of white sweet potatoes (Yuliana et al. 2014). According to Liao and Wu (2017), the lengthy treatment of fermentation destroyed the crystal structure of sweet potato starch and significantly affected the crystalline and amorph parts. The activity of lactic acid bacteria allegedly caused this. The size of starch granules in the white sweet potato fermentation process could change after the fermentation process (Yuliana et al. 2014).

\section{Isolation and screening of EPS-producing lactic acid bacteria}

Sixty isolates from back-slopping fermentation that had transparent zone colonies were selected as presumptive lactic acid bacteria. An example of these colonies is presented in figure 2A. All of these bacteria were confirmed lactic acid bacteria as all strains had Grampositive, negative endospore, and negative catalase test. Besides, most of the strains were the creamy color with a circular form, entire margin, and flat elevation, the general colony performance of lactic acid bacteria. A previous study reported that the characteristic of the lactic acid bacteria was a white-round or oval colony, convex elevation, gram-positive bacteria, and a rod-shape (bacilli) (Astriani et al. 2018). Most of the isolates had rod-shaped cells (53 isolates), and the remaining was cocci-shape (7 isolates). Subsequent screening of these 60 lactic acid bacteria isolates resulted in 34 positive results $(56.67 \%)$ that able to produce a polymer in the MRS modified medium. EPS production potential was indicated by a transparent or creamy material involving a mucoid colony (Figure 2B). The number of EPS by colonies was confirmed by the presence of crude EPS in the form of precipitation form. This formation has occurred after each mucoid was mixed in absolute alcohol. The EPS, matrix polysaccharides, confirmed by electron microscopy analyses, were presented in Figure 2.C-E. Although the EPS-producing lactic acid bacteria were present at a low frequency, they could be used as starter cultures or adjuncts in mixed cultures to modify sweet potato flour.

Amongst 34 positive results isolates that able to produce a polymer in MRS modified medium, only four isolates (namely $\mathrm{C} 2, \mathrm{~A}, \mathrm{E}, \mathrm{N}$ ) having more than $1.4 \mathrm{~mm}$ diameter index of mucoid, and four isolates, namely $\mathrm{L}, \mathrm{P}$, $\mathrm{Q}$, and $\mathrm{V}$, produced crude EPS with high results (more than $0.1 \mathrm{~g} / \mathrm{ml}$ ) either on the agar medium containing skim milksucrose or on the MRSB medium containing 3\% sucrose (Table 2). Meanwhile, the second high EPS-producing isolates $(0.06-0.09 \mathrm{~g} / \mathrm{ml})$ were $\mathrm{C} 2, \mathrm{~A}, \mathrm{E}, \mathrm{F}, \mathrm{L} 1, \mathrm{~N}, \mathrm{O}, \mathrm{O} 1$, $\mathrm{W}, \mathrm{X}$, and among this, it was only four isolates (namely $\mathrm{C} 2, \mathrm{~A}, \mathrm{E}, \mathrm{N}$ ) having more than $1.4 \mathrm{~mm}$ diameter index of mucoid. Therefore, the eight strains (namely C2, A, E, L, $\mathrm{N}, \mathrm{P}, \mathrm{Q}$, and $\mathrm{V}$ ) were selected for the subsequent experiment.

Based on a physiological test, most of these isolates grew well in the temperature of $28-45^{\circ} \mathrm{C}$, and the $\mathrm{NaCl}$ concentration of $3-4.5 \%$. One isolate was slightly halophilic bacteria as they may grow at the concentrations of $3 \% \mathrm{NaCl}$, while the other isolates were moderately halophilic for being the ability for growth at 4 to $8 \% \mathrm{NaCl}$. The occurrence of halophilic lactic acid bacteria of this study is probably contributed to the origin of the product. These bacteria isolated from sweet potatoes pickle where 3$6 \%$ salt was added during its preparation. Based on the ability to grow in salt concentration media, bacteria may be grouped as slightly halophilic $(2-5 \% \mathrm{NaCl})$, moderately halophilic $(5-15 \% \mathrm{NaCl})$, and extremely halophilic for growth at a concentration of 15-30\%) (Yadav et al. 2015). Tolerances to grow on media with varying $\mathrm{NaCl}$ salt levels are different depending on the genus of lactic acid bacteria (Ismail et al. 2018).

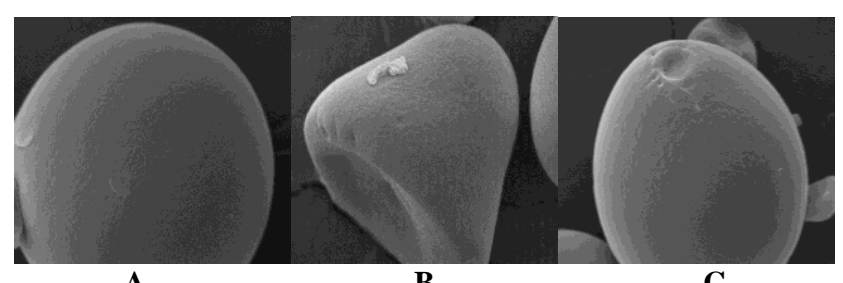

A

B

C

Figure 1. The appearance of yellow sweet potato starch granules: A. Control, without fermentation, B. Spontaneous 72 hours, C. Back-slopping 72 hours

Table 2. Diameter index of the mucoid colony and weight of EPS produced by isolates on LEL medium

\begin{tabular}{lccc}
\hline Code & EPS weight $(\mathbf{g} / \mathbf{m L})$ & $\begin{array}{c}\text { Index diameter of } \\
\text { mucoid (mm) }\end{array}$ & Number of colony \\
\hline C4, A15 A1, A2, A3, A4, A5, A6, A7, A8, A14, & $0.001-0.003$ & $1.27-1.40$ & 2 \\
B3, B6, B7, C, C3, C8, Y, Q1, U & $0.01-0.05$ & $1.23-1.56$ & 18 \\
C2, A, E, F, L1, N, O, O1, W, X & $0.06-0.09$ & $1.27-1.58$ & 10 \\
Q, V & $0.1-0.4$ & 1.41 & 2 \\
L, P & $1.13-1.18$ & $1.28-1.54$ & 2 \\
Total colony & & & 34 \\
\hline
\end{tabular}




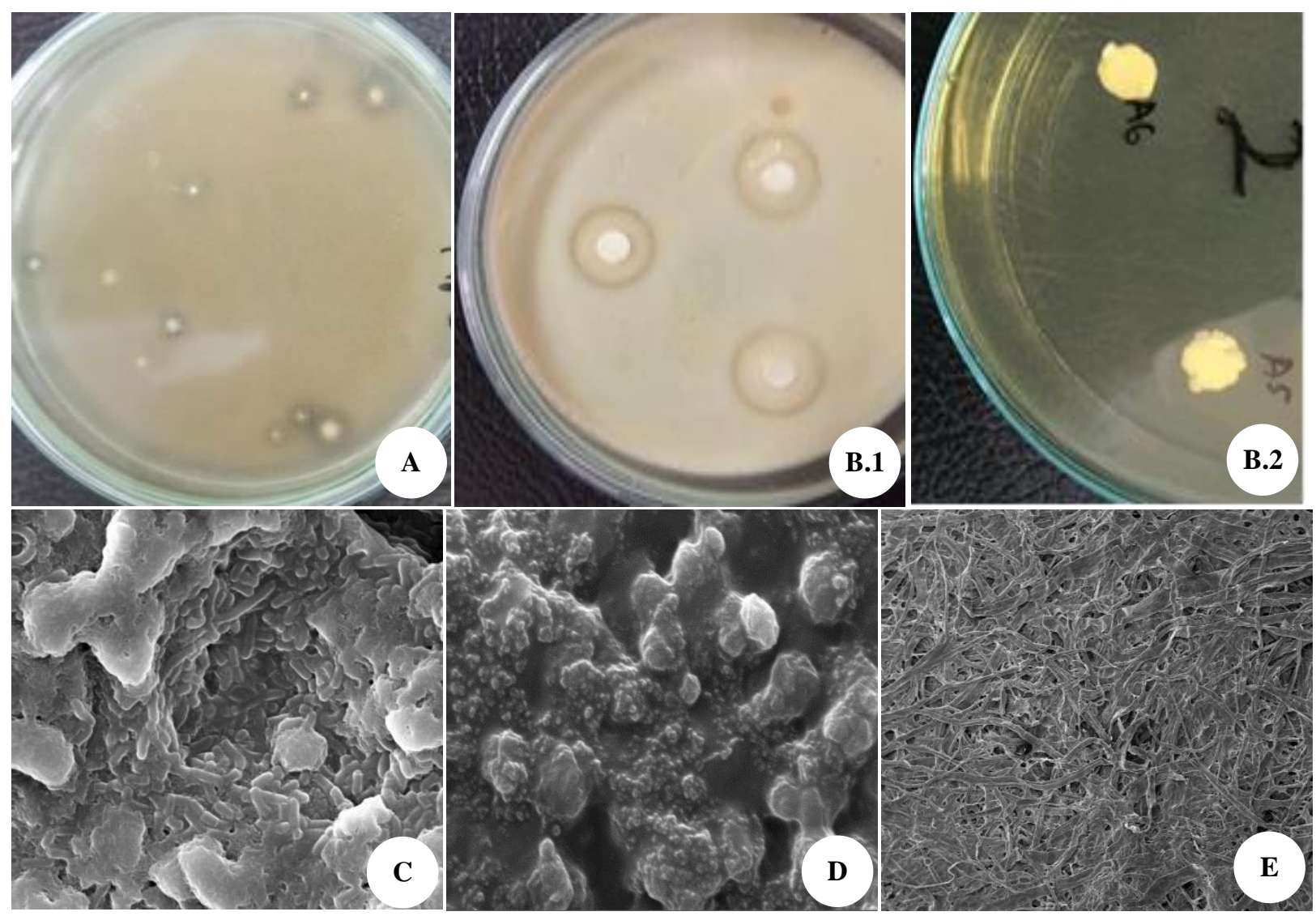

Figure 2. A. Lactic acid bacteria colonies, B. Mucoid colony, C. Paper disc containing EPS-producing bacteria ( $\times 7000$ magnification), D. Paper disc containing EPS only without bacteria cell ( $\times 7000$ magnification), E. Negative control, a paper disc without inoculation of bacteria $(\times 1000$ magnification $)$

The endurance test for the growth temperature showed that all isolates grew well at $28^{\circ} \mathrm{C}$, and seven strains of these can survive until $45^{\circ} \mathrm{C}$, where four isolates among these can survive at temperatures of $50^{\circ} \mathrm{C}$. These results indicated that most of these isolates were thermophilic lactic acid bacteria. Isnawati and Trimulyono's (2018) study showed that lactic acid bacteria were able to grow at a range of 4 to $50^{\circ} \mathrm{C}$. The thermophilic lactic acid bacteria as an EPS producing were not surprising as reported by previous studies (Zhang et al. 2011; Panthavee et al. 2017; Khanal and Lucey 2018).

\section{Comparison of potentially EPS-producing LAB on various medium}

The effect on different four carbon sources (glucose, galactose, lactose, and sucrose) on the production of exopolysaccharide (EPS) produced by selected isolates was investigated. The exciting result showed that four different carbon sources have varying degrees of a stimulatory effect on EPS production. Isolates $\mathrm{A}, \mathrm{E}, \mathrm{L}, \mathrm{N}, \mathrm{Q}$, and $\mathrm{V}$, had the maximum EPS yield when sucrose was employed. In contrast, an isolate of $\mathrm{P}$ and $\mathrm{C} 2$ were favorable to galactose, and lactose, and sucrose, respectively (Table 3).
Table 3. The EPS $(\mathrm{mg} / \mathrm{mL})$ yield of selected isolates on carbon sources.

\begin{tabular}{lllll}
\hline \multirow{2}{*}{ Isolates } & \multicolumn{4}{c}{ EPS $(\mathbf{m g} / \mathbf{m L})$ yield on several Carbon Sources } \\
\cline { 2 - 5 } & Glucose & Galactose & Lactose & Sucrose \\
\hline C2 & $1.73 \pm 0.13$ & $3.40 \pm 0.21$ & $4.00 \pm 0,09$ & $4.20 \pm 0.10$ \\
A & $4.40 \pm 0.26$ & $0.73 \pm 0.08$ & $0.00 \pm 0.00$ & $1.93 \pm 0.23$ \\
E & $3.80 \pm 0.16$ & $2.67 \pm 0.35$ & $0.00 \pm 0.00$ & $1.20 \pm 0.13$ \\
L & $4.30 \pm 0.12$ & $3.40 \pm 0.03$ & $2.73 \pm 0.01$ & $3.47 \pm 0.25$ \\
N & $6.20 \pm 0.16$ & $0.10 \pm 0.00$ & $0.20 \pm 0.00$ & $2.40 \pm 0.33$ \\
P & $5.27 \pm 0.37$ & $6.60 \pm 0.16$ & $6.60 \pm 0.46$ & $4.07 \pm 0.29$ \\
Q & $3.93 \pm 0.18$ & $0.13 \pm 0.00$ & $0.07 \pm 0.00$ & $2.27 \pm 0.32$ \\
V & $8.07 \pm 0.06$ & $0.73 \pm 0.08$ & $0.07 \pm 0.00$ & $1.60 \pm 0.23$ \\
\hline
\end{tabular}

Note: The results are mean of triplicates determination \pm standard deviation.

Several LAB produces polysaccharides that secreted into the environment as exopolysaccharides (EPS) (Zeidan et al. 2017). In this study, the favorable carbon sources for the growth and production of EPS were isolated dependent. According to EPS yield in Table 2, however, glucose was shown to sustain high rates in carbon conversion efficiency. The influence of the type of carbon sources on 
EPS production was confirmed by many authors (Rabha et al. 2012; Razack et al. 2013; Jaiswal et al. 2014). Amongst isolates, the highest yield of crude EPS was produced by $\mathrm{V}$ isolate $(8.07 \mathrm{mg} / \mathrm{mL})$ on glucose, following by $\mathrm{P}(6.60$ $\mathrm{mg} / \mathrm{mL})$ on galactose and lactose, and $\mathrm{N}(6.20 \mathrm{mg} / \mathrm{mL})$ on glucose medium respectively. With this high yield, these isolates can be developed as good starters for EPS production. Therefore, further research is necessary to elucidate the EPS effect on functionality and aroma of fermented SP flour with these potential starters.

In conclusion, the potential starter can be taken from the yellow sweet potato fermentation by the back-slopping method, at 72 hours, as this showed the excellent value for the production of EPS metabolites, supported by the amount of LAB, total lactic acid and the lowest $\mathrm{pH}$ as well. Screening on the sixty strains of lactic acid bacteria isolated from fermented sweet potatoes pickle, 34 isolates were found to have EPS-producing ability. Amongst these, the eight highest EPS-producing strain was a promising possibility to be further developed as a starter. Most of these were favorable growth at $3 \%$ salt, glucose as carbon sources, and $28-45^{\circ} \mathrm{C}$ of growth temperature.

\section{ACKNOWLEDGEMENTS}

The authors were very grateful to University of Lampung, Indonesia through Hibah Professor for funding this study.

\section{REFERENCES}

Ajayi OI, Ehiwuogu-Onyibe JI, Oluwole OB, Jegede AA, Salami TAI, Asieba GO, Chiedu IE, Suberu YL, Aba M, Dike EN, Jebor FN, Elemo GN. 2016. Production of fermented sweet potato flour using indigenous starter cultures. Afr J Microbiol Res 10: 1746-1758.

Ajayi OI, Okedina TA, Samuel AE, Asieba GO, Jegede AA, Onyemali CP, Ehiwuogu-Onyibe J, Lawal AK, Elemo GN. 2019. Evaluation of starter culture fermented sweet potato flour using FTIR spectra and GCMS chromatogram. Afr J Microbiol Res 13 (1): 1-13.

Amajor JI, Oti E, Ekeledo N, Omodamiro R, Amajor EE, Aniedu C. 2014 Studies on the characteristic properties of fermented, sun-dried orange-fleshed sweet potato flour. Niger Food J 32: 45-53.

Amal AM. 2015. Quality evaluation of wheat-sweet potato composite flours and their utilization in bread making. Intl J Adv Res Biol Sci 2 : 294-303.

Anino C, Onyango A, Imathiu S, Maina J. Effect of lactic acid bacteria starter cultures on vitamin and oligosaccharide composition of milk extracted from three common bean (L) varieties. J Food Res 8 (3): 103-110.

Aprianita A, Purwandari U, Watson B, Vasiljevic T. 2009. Physicochemical properties of flours and starches from selected commercial tubers available in Australia. Intl Food Res J 16: 507-520.

Astriani A, Diniyah N, Jayus J, Nurhayati N. 2018. Phenotypic identification of indigenous fungi and lactic acid bacteria isolated from 'gatot' an Indonesian fermented food. Biodiversitas 19 (3): $947-$ 954.

Bintsis T. 2018. Lactic acid bacteria as starter cultures: An update in their metabolism and genetics. AIMS Microbiol 4: 665-684.

De Vuyst L, Van Kerrebroeck S, Leroy F. 2017. Microbial ecology and process technology of sourdough fermentation. Adv Appl Microbiol 100: 49-160.

Díaz A, Dini C, Viña SZ, García MA. 2018. Technological properties of sour cassava starches: Effect of fermentation and drying processes. Lwt Food Sci Technol 93: 116-123
Guo L, Tao H, Cui B, Janaswamy S. 2019. The effects of sequential enzyme modifications on structural and physicochemical properties of sweet potato starch granules. Food Chem 277: 504-514.

Ismail YS, Yulvizar C, Mazhitov B. 2018. Characterization of lactic acid bacteria from local cow's milk kefir. IOP Conf Ser: Earth Environ Sci 130 (1): 012019. DOI: 10.1088/1755-1315/130/1/012019.

Isnawati, Trimulyono G. 2018. Temperature range and degree of acidity growth of isolate of indigenous bacteria on fermented feed. The 2nd International Joint Conference on Science and Technology (IJCST) IOP Conf Ser: J Phys: Conf Ser 953: 012209. DOI: 10.1088/17426596/953/1/.

Jaiswal P, Sharma R, Sanodiya BS, Bisen PS. 2014. Microbial exopolysaccharides: Natural modulators of dairy products. J Appl Pharm Sci 4: 105-109. DOI: 10.7324/JAPS.2014.40119.

Khanal SN, Lucey JA. 2018. Effect of fermentation temperature on the properties of exopolysaccharides and the acid gelation behavior for milk fermented by Streptococcus thermophilus strains Dgcc7785 and St-143. J Dairy Sci 101: 3799-3811.

Karasu EN, Ermis E. 2019. Determination of the effect of exopolysaccharide (EPS) from Lactobacillus brevis E25 on adhesion of food powders on the surfaces, using the centrifuge technique. J Food Eng 242: 106-114.

Kurniadi M, Arsyad MF, Sar AM, Nurhayati R, Wiyono T. 2019. The effect of fermentation duration and starter concentration on physicochemical properties of modified sorghum flour by Lactobacillus plantarum FNCC 0027. Food Res 3: 441-447.

Leroy F, De Vuyst L. 2016. Advances in production and simplified methods for recovery and quantification of exopolysaccharides for applications in food and health 1. J Dairy Sci 99: 3229-3238.

Liao L, Wu W. 2017. Fermentation effect on the properties of sweet potato starch and its noodle's quality by Lactobacillus plantarum. J Food Process Eng 40: e12460. DOI: 10.1111/jfpe.12460.

Maalej H, Hmidet N, Boisset C, Buon L, Heyraud A, Nasri, M. 2014. Optimization of exopolysaccharide production from Pseudomonas stutzeriAS22 and examination of its metal-binding abilities. J Appl Microbiol 118: 356-367.

Othman M. Ariff AB, Rios-Solis L, Halim M. 2017. Extractive fermentation of lactic acid in lactic acid bacteria cultivation: a review. Front Microbiol 8: 2285. DOI: 10.3389/fmicb.2017.02285

Oloo BO, Shitandi A, Mahungu S, Malinga JB, Ogata BR, 2014. Effects of lactic acid fermentation on the retention of beta-carotene content in orange-fleshed sweet potatoes. Intl J Food Stud 3: 13-33.

Onilude AA, Olaoye O, Fadahunsi IF, Owoseni A, Garuba O, Atoyebi T. 2013. Effects of cultural conditions on dextran production by Leuconostoc spp. Intl Food Res J 20: 1645-1651.

Panthavee W, Noda M, Danshiitsoodol N, Kumagai T, Sugiyama M. 2017. Characterization of exopolysaccharides produced by thermophilic lactic acid bacteria isolated from tropical fruit of Thailand. Biol Pharm Bull 40: 621-629.

Patel A, Prajapati JB. 2013. Food and health applications of exopolysaccharides produced by lactic acid bacteria. Adv Dairy Res 1: $1-7$.

Paulo EM, Vasconcelos MP, Oliveira IS, Affe HMJ, Nascimento R, de Melo IS, Roque MRA, de Assis SA, 2012. An alternative method for screening lactic acid bacteria for the production of exopolysaccharides with a rapid confirmation. Food Sci Technol 32: 710-714.

Petrova P, Petrov K, Stoyancheva G. 2013. Starch-modifying enzyme of lactic acid bacteria, structure, properties and application. Starch/Starke 65: 34-37.

Rabha R, Nadra R-S, Ahmaed B. 2012. Effect of some fermentation substrates and growth temperature on exopolysaccharide production by Streptococcus thermophilus BN1. Intl J Biosci Biochem Bioinforma 2: 44-47.

Ramakrishnan S, Rathnasamy SK. 2016. $\beta$ amylase purification from sweet potato (Ipomoea batatas): Reverse micellar extraction versus ammonium sulphate precipitation. Der Pharmacia Lettre 8: 118-125.

Rawal PM, Chauhan PB, Prajapati H, Gahlou M. 2016. Evaluation of cultivation condition for enhanced production of exopolysaccharide by bacterial isolate P 11 under submerged culture condition. Intl J Adv Res Biol Sci 3: 183-190.

Razack SA, Velayutham V, Thangavelu V. 2013. Medium optimization for the production of exopolysaccharide by Bacillus subtilis using synthetic sources and agro wastes. Turk J Biol 37: 280-288.

Rodrigues NDR, Barbosa Junior JL, Barbosa MIMJ. 2016. Determination of physicochemical composition, nutritional facts and technological 
quality of organic orange and purple-fleshed sweet potatoes and its flours. Intl Food Res J 23: 2071-2078.

Thorat SPP, Sadawarte SK, Sawate AR, Machewad GM. 2017. Original studies on the effect of fermentation on physicochemical properties of vegetables and preparation of sauce. Intl J Curr Microbiol Appl Sci 6 : 3537-3545.

Trejo-González AS, Loyo-González AG, Munguía-Mazariegos MR. 2014. Evaluation of bread made from composite wheat-sweet potato flours. Intl Food Res J 21: 1683-1688.

Vidra VA, Tóth AJ, Németh A. 2017. Lactic acid production from cane molasses. Liq Waste Recovery 2: 13-16.

Vrancken G, Rimaux T, Weckx S, Leroy F, De Vuyst L. 2011. Influence of temperature and back slopping time on the microbiota of a type I propagated laboratory wheat sourdough fermentation. Appl Environ Microbiol 77: 2716-2726.

Yadav D, Singh A, Mathur N. 2015. Halophiles-a review. Intl J Curr Microbiol Appl Sci 4: 616-629.

Yuliana N, Nurdjanah S, Sugiharto R, Amethy D. 2014. Effect of spontaneous lactic acid fermentation on physicochemical properties of sweet potato flour. Microbiol Indonesia 8: 1-8.

Yuliana N, Nurdjanah S, Setyani S, Novianti D. 2017. Improving properties of sweet, potato composite flour: Influence of lactic fermentation. AIP Conf Proc 1854: 020040. DOI: 10.1063/1.4985431.

Yuliana N, Nurdjanah S, Dewi YR. 2018. Physicochemical properties of fermented sweet potato flour in wheat composite flour and its use in white bread. Intl Food Res J 25: 1051-1059.

Yuliana N, Nurdjanah S, Margareta M. 2013. The effect of a mixed-starter culture of lactic acid bacteria on the characteristics of pickled orangefleshed sweet potato (Ipomoea batatas L.). Microbiol Indones 7: 1-8.

Zajsek K, Gorsek A, Kolar M. 2013. Cultivating conditions effects on kefiran production by the mixed culture of lactic acid bacteria imbedded within kefir grains. Food Chem 139: 970-977.

Zeidan AA, Poulsen VK, Janzen T. Buldo P, Derkx PMF, Øregaard G, Neves AR. 2017. Polysaccharide production by lactic acid bacteria: from genes to industrial applications. FEMS Microbiol Rev 41 (Supp_1): S168-S200.

Zhao J, Dong Z, Li J. 2019. Effects of lactic acid bacteria and molasses on fermentation dynamics, structural and nonstructural carbohydrate composition and in vitro ruminal fermentation of rice straw silage. Asian Austral J Anim 32: 783-791. DOI: 10.5713/ajas.18.0543.

Zhang Y, Li S, Zhang C, Luo Y, Zhang H, Yang Z. 2011. Gowth and exopolysaccharide production by Lactobacillus fermentum F6 in skim milk. Afr J Biotechnol 10: 2080-2091. 